\title{
LEGAL ISSUES ON PLEDGE SHARE AGREEMENT
}

\author{
Suharnoko $^{1}$
}

\begin{abstract}
The creditors are considered as unsecured creditors if they are relying only to article 1131 and 1132 of the Civil Code. In order to become a secured creditor, a security agreement must be made. Many financial institutions are now prefer securing its credit by pledge of shares of customer's enterprise. This article focuses on the legal issues regarding the validity and execution on the pledge share agreement.
\end{abstract}

\section{Introduction}

Banks are financial institution performing their function as financial intermediary. Banks pool the capital from people and lend it to business associations and companies. Most of these activities have been going for centuries and the most common practice for business to obtain fund are to have loan agreements with banks or other financial institutions. Financial institutions make profit through the return of payments performing by their debtor acting with good faith.

Banks must apply the five principles of duty of care in doing the business of corporate financing, such as, providing credits to business sector. Those five principles are character, capacity, capital, collateral and condition of economy and another principle that is constant. Therefore, even though article 1131 the Civil Code mentions that all debtors' properties by operation of law is subject to his creditors' claims, it probably cannot be satisfied his creditors' claims in case the value of his property is less that his debt. According to article 1132 the Civil Code, in case the debtor doesn't satisfy his obligation to make payment, such properties would be subject to judicial sale and a result of such sale shall be proportionally divided to his creditor regarding to the amount of each creditor claim. Every creditor only receives payment proportionally to the amount of his claim. Moreover, it is possible for the debtor to convey his properties. The properties belong to the third party are not subject to article 1131 of the Civil Code. The creditors are considered as unsecured creditors if they are relying only to article 1131 and 1132 of the Civil Code.

For that reasons the creditor asks the debtor to provide security by means of special contract. The character of special contract is accessory to the main agreement, such as loan agreement or funding between the creditor and its debtor. The security agreement is divided into guarantee contract and security right in rem. The personal guarantee is security concerning a statement on a performance given by third party to guarantee the fulfillment of debtor's obligation toward the creditor in the event that the debtor in question fails to perform. Such guarantee could be in the form of personal guarantee, bank guarantee or corporate guarantee. Whereas the security

${ }^{1}$ Lecturer at Faculty of Law University of Indonesia 
right in rem can be divided into pledge, fiduciary transfer of ownership, mortgage and security transaction over the land and its affixed building. The characteristic of such security agreement is that, securities follow the encumbered properties. Moreover, the secured creditor who obtains preference position is satisfying his claim toward unsecured creditor. According to article 56 of Bankruptcy Act, every creditor holding security right, such as pledge, fiduciary transfer of ownership, mortgage and security transaction over land and its affixed building will not influenced by a bankruptcy decision. Such creditors protected by security transaction are considered secured creditors. As a secured creditor the pledgee may execute pledged shares as if there is no bankruptcy on pledgor. However, the article $56 \mathrm{~A}$ of the Bankruptcy Law provides that the creditor right to execute such secured transaction and the bankrupt or creditor is postponed for a period of ninety days at the latest, calculated from the date the bankruptcy decision has been determined.

The requirement that pledged tangible property shall be convey from debtor possession to the creditor often causes serious obstacle to utilize the pledge in commercial transaction to creditor property. Banks as Creditors-Pledgees must keep in custody such pledged tangible property, and therefore according to Sudargo Gautama, they prefer securing its credit by pledge of shares of the customer's enterprise. ${ }^{2}$ For comparison, according to Sri Soedewi Masjchun Sofwan, under the Meijers law the Netherlands introduced pledge without physical possession or bezitloss pandrecht and registered pledge or registerpandrecht. ${ }^{3}$

\section{Laws and Regulations on Pledge of Shares}

Personal property which is tangible or intangible can be encumbered by pledge. The pledgor cannot retain the physical possession of pledged property. He must release and deliver the property to the creditor or third party. The reason of this rule is to protect the interest of the creditor holding the said pledge. If the debtor or pledgor retain possession of the movable good, it is possible for him to dispose it to the third party. According to article 1977 (1) of the Civil Code is to facilitate trading on movable goods. As a result, a buyer with good faith will be protected against the claim proposed by the owner of said good or the claim proposed by the pledge. It is not necessary for the buyer to investigate whether the seller is the owner of movable good or not. Therefore according to article 1152 Paragraph 2 of the Civil Code, the removal of the pledged property from the possession of pledgor is mandatory for valid pledge. If the pledgor retains or recovers possession of encumbered property with the pledgee's consent as a consequence the pledge is void. However if the pledgee recover possession or control over the said property, he is considered never to have lost possession. In order to have a valid pledge for tangible movable property and a lien to bearer, according to article 1152 paragraph one, of the Civil Code, a bearer instrument must be released from the possession of pledgor whereas for lien to order, according

${ }^{2}$ Sudargo Gautama. (1995). Introduction to Indonesian Business Law. Bandung PT. Citra Aditya Bakti. p. 583.

${ }^{3}$ Sri Soedwi Masjchun Sofwan. (1977). Beberapa Masalah Pelaksanaan Lembaga Jaminan Khusus Fiducia di Dalam Praktek dan Perkembagannya di Indonesia. Jogjakarta: FH UGM. p. 55. 
to article 1152 bis the Civil Code, a creation of pledge requires endorsement of the instrument and delivery to the pledge or third party.

In case the debtor pledges his personal line such as, personal/share registered shares in corporation, such pledge must be notified to the corporation. Based on the article 1153 of the Civil Code such notification is a requirement for the for the validity of pledge of share, since such pledge of shares will be executed toward a corporation. Frieda Husni Hasbullah in her book had mentioned the important of notification for validity of pledged personal lien. ${ }^{4}$

All shares of company are registered shares. Under the Corporation Law of 2007 No. 40, personal shares or registered shares can only be pledged of it is allowed by the Article of Association. Moreover the company should maintain a Register of Shareholder and based on article 60 of the Corporation Laws, the pledge of share must be registered. The shareholder obtain rights to vote in the shareholder meeting, right to dividends and right in the balance on the corporation's property after it has been liquidated. However, in case the corporation's shares are pledged, the voting right is remain to the shareholder.

According to Fred Tumbuan SH in his presentation "Presentation on New Company Law", the right to vote is an inseparable part attached to the share in question and therefore it cannot be transferred from the relevant share. As a legal consequence, in case of pledge or fiduciary security interest, the right to vote in encumbered shares remain vested in the shareholder. The irrevocable power of attorney to vote will not change this rule that the shareholder still maintains the right to vote in the shareholder general meeting. ${ }^{5}$

For comparison, H. J. Snijders in his paper "Pledge in General and Pledge of Shares in Particular including the enforcement under Netherlands Law", mentions that based on article 2:89 and article 198 New Burgerlijk Wetboek, the shareholder shall have the right to vote in general meeting, unless this right is attributed to the pledgee. According to H. J. Snijders a pledgee can benefit a great deal by exercising voting right to influence the company, such as to transfer the company or company subsidiary. ${ }^{6}$

The character of pledge is accessory to the main contract, such as a loan agreement. The occurrence of pledge depends on the main contract. In the circumstance that the debtor has satisfied his obligation by paying his debt then the pledge will be extinct. Ownership of such pledged property is not conveyed from the pledgor to the pledgee. Moreover, when the debtor is in default, de pledge I not entitle to appropriate such pledged property without the court permission. Based on article 1154 of the Civil Code, an agreement concerning the pledgee's right to appropriate the encumbered property is null and void.

Furthermore, according to article 1155 paragraph 1 of the Civil Code, the right of pledgee is to sell the pledged property by public auction without the court's permission and to satisfy his claim from the proceeds. If the creditor as pledgee wants to dispose such pledged property by private sale, according to article 1156 of the Civil

\footnotetext{
${ }^{4}$ Frieda Husni Abdullah. (2005). Hukum Kebendaan Perdata. Jakarta: Ind-Hill Co. p. 31.

${ }^{5}$ Fred B. G. Tumbuan. (2007). Presentation on New Company Law in Seminar Sehari Aspek-Aspek Penting tentang Undang-Undang No. 40 tahun 2007. Jakarta: November 2007, p. 11.

${ }^{6}$ H. J. Snijder. (2010). Pledge in General and Pledge of Shares in Particular including the Enforcement under Netherlands Law in Seminar Eksekusi Saham. Jakarta: 31 March 2010. p. 7.
} 
Code he must obtain the court's consent and it is possible for the pledgee to request the court's permission to keep the pledged property in satisfaction of his claim. The court will calculate and fix the amount to be paid by the pledgee for requirement to retain the encumbered good as his own property.

With regard to shares registered and traded at Stock Market, article 1.1. jo. Article 3.6.1 of Regulation issued by Securities Custodian Centre (Keputusan Direksi KSEI No. KEP. 012/DIR/KSEI/0806) that a person registered as the owner of security account may encumber his securities by way of making application to the Securities Custodian Central. Furthermore article 3.6.2 Peraturan KSEI mentions that encumbered securities must be registered at security account and such encumbered securities cannot be traded for settlement of security trading.

Article 1155 paragraph 2 of the Civil Code deals with the execution of the noted pledged shares at the stock market. It provides that the judicial sale shall be performed at stock market by two expert brokers in such trading property.

Legal issues on Validity and Execution of Share Purchase Agreement:

a. The nature of pledge share agreement is dependent or accessory to loan agreement as the main contract. In case the duration of share pledge agreement is limited before the debt is paid up, the question is whether to extend the said pledge creditor shall obtain consent from the debtor, or he just notify his debtor?

b. Article 1152 paragraph 2 of the Civil Code states that in case the pledgee is not entitle to encumber pledge on the good, it shall not make the creditor responsible for that, without abolishing the right of the owner to reclaim it. The legal issue is in case the creditor know that the debtor-pledgor is not entitle to pledge his shares, it is possible for the third party to ask the court to invalidate the share pledge agreement?

c. Article 1154 of the Civil Code states that in case the debtor is in default, the creditor shall not appropriate the pledged good and all agreement contrary to this provision is null and void. As a practical matter, to execute pledged of share, the creditor ask debtors to make irrevocable power of attorney to creditors for selling the said encumbered shares in private. It is stipulated in the irrevocable power of attorney that the creditor have the authority to decide how the said pledged shares will be disposed and to fix the price of them as well. The legal issue is whether such irrevocable power of attorney is constitute appropriation of the encumbered property, since it was made prior the event of default?

d. Article 1155 paragraph 1 of the Civil Code mentions that unless it has been agreed between the parties, the creditor is entitled to sell the pledged good publicly without court order when the debtor is in default to pay his obligation. The legal issues is whether the right of creditor to sell the pledged shares without court order is legally by operation of law or it shall be agreed by the creditor and the debtor similarly to the provision in mortgage? Another legal issue, article 56 of the Law No. 40 Year 2007 concerning Corporation states that the transfer of title for personal share shall be made by the deed of transfer 
of title, so with regard to that law, is it possible to perform execution by judicial sale through auction for personal share?

e. In case the pledged shares are registered in stock exchange, according to the rule issued by KSEI (Central Custodian Centre), such pledged shares shall be registered in debtor security account. How to protect the interest of creditor since the debtor is still entitle to deregistered it? Moreover, Banks face fluctuation of price at the stock market, but under the Banking Law, for the purpose of execution, bank may cash the pledged property as soon as possible by way of auction. Whereas article 1155 paragraph 2 of the Civil Code says that in case the pledged good is consist of merchandise of stock traded in the market or stock exchange, then the selling of such pledged good shall be performed by two professional brokers. The question is which Law is applicable?

f. Facing the issue of appropriation, usually creditors file petition to the District Court as to ask the court to issue the court decrees legalizing such irrevocable power of attorney to sell. The legal issue is whether the creditor shall bring the case to sue the debtor in the court in order to have the court verdicts or is it enough for the creditor to file petition to the court in order to have the court decrees that legalizing the sale of said encumbered shares? Another issue is shall the pledged shares be sold in public or in private?

\section{Case Analysis}

\section{The First Legal Issue}

The character of share pledge agreement is accessory (French: accessoir) to main contract. Therefore by virtue of its character as accessory contract, the pledge share agreement shall be exist as long as the debtor have not perform its obligation to pay its debt to the creditor. However when the duration of pledge share agreement is limited, it is necessary for the creditorpledgee to obtain approval from the debtor-pledgor to extend it or the creditor just make notification?

Article 1343 of the Civil Code states that if the wording of an agreement may be interpreted in various way it should be considered what might have been the intent of both parties consent rather than to be bound by the literal meaning. For example, in the case of PT APT vs PT BFI, according to shareholder's meeting of PT APT dated May 1999, the purpose of share pledge agreement was to secure PT APT obligations to PT BFI based on domestic recourse agreement and financial leasing agreement. Therefore in my opinion, if the PT BFI wants to extent the said pledge agreement, it is not necessary for PT BFI to obtain approval from PT APT. However the Supreme Court in case No. 204PK/PDT/2006 dated 20 February 2007 held that the share pledge agreement and its amendments was void since 1 December 2000 due to limit duration.

In another case, PT OMC vs PT BFI, the Supreme Court case No. 1478K/Pdt/2005 dated 205 October 2005 confirmed the Jakarta Court of 
Appeal's verdict. It stated that as long as the debt had not been paid up then the share pledge agreement is still valid. It seems that the Supreme Court followed legal doctrine that saw the nature of share pledge agreement is independent to debt arise out from the main contract. However the Supreme Court in case No. 115/PK/Pdt/2007 dated 19 July 2007 held that even though the share pledge agreement is still valid but PT BFI shall not execute the share pledge agreement by using irrevocable power of attorney.

\section{The Second Legal Issue}

Under the article 1152 paragraph 4 of the Civil Code, in case the pledgor is not entitle to pledge the property, it shall not make the pledgee responsible for that. It means that the pledge is still valid. However, in my opinion, in the case creditor-pledgee know or supposed to know that the debtor-pledgor is not entitle to pledge its shares, the third party with good faith may ask the court to declare that such pledged of shares is null and void. Even though article 1340 of the Civil Code constitutes the doctrine of privity of contract, the agreement shall not cause damage to the third party. Furthermore article 1341 of the Civil Code provides that the creditor may ask the court to declare that such agreement between his debtor and another party is void. The law imposes the burden of proof to the creditor. Alternatively, the creditor may bring this kind of case under tort claim since to bring tort case it is not necessary to establish contractual relationship between the plaintiff and the defendant.

The case between the Government of Republic of Indonesia and PT Newmont Nusa Tenggara (PT NNT) is about the contract of work between the Indonesian government and PT NNT with divestiture obligation. However, PT NNT and its shareholders pledged their share to the Bank of Tokyo. The UNCITRAL Tribunal held in favor of the Government of Republic of Indonesia, so that PT NNT transfer the divestiture share to an entity designated by the regional government and the divestiture have to be unencumbered. In my opinion the Tribunal Final Award is correct. The bank of Tokyo with its reputation as professional banking was supposed to know that such pledged shares is subject to divestiture obligation. Moreover according to article 1492 of the Civil Code, although no warranty has been stipulated at the time of the sale, the seller is nonetheless by operation of law obligated to indemnify the buyer against eviction from the whole or part of property or against encumbrances which may be claimed on the property and which were not disclosed at the time the sale was concluded.

\section{The Third Legal Issue}

In the event of default, all of the shareholder irrevocably and unconditionally empower the bank to its sole discretion determine the pledged of share at public sale of private sale. This power of attorney with the right of substitution and all other powers conferred on integral in separable part of this Share Pledge Agreement without which the Bank would not have entered into 
the Facility Agreement is therefore irrevocable and will not terminate by reason of any of the matters referred to in articles 1813, 1814 and 1816 of the Civil Code.

The use of irrevocable power of attorney raises the legal issue whether it constitute appropriation of the encumbered property or not? The ration underlying article 1154 of the Civil Code is that the value of pledged property is usually higher than the amount of debt and therefore the creditor shall not appropriate the pledged property when the debtor cannot perform its obligation to make payment. However according to J. Satrio, article 1154 of the Civil Code is not to make applied for personal lien including personal share, since in personal lien the nominal value of such lien is already fixed. On the contrary, if the value of pledged property is determined by the result of sale, then there is opportunity for the creditor to abuse its authority in determining the price. ${ }^{7}$ J. Satrio also mentions that article 1156 of the Civil Code, provides a useful execution procedure for pledged property without market price. ${ }^{8}$ In addition to that, according to Fred B. G. Tumbuan, in his legal opinion in The High Court of the Republic of Singapore concerning the case between Beckket PTE Ltd. versus Deutsche Bank AG and PT Dianlia Setyamukti, the requirement under article 1156 that the Court determine and stipulate the value of the pledged property to a third party other than by way of public auction.

Therefore, if the pledged property is personal share, then there is no restriction to have irrevocable power of attorney to sell and it does not constitute an appropriation. However, according to Soenardi Pardi, in his paper "The Current Development of the Enforcement of a Pledge of Shares in Indonesia", a sale and delivery made by the pledgee under a power of attorney itself is not enforcement of a pledge. Technically for the purpose of delivery the pledge need to be first annulled. Moreover, this power of attorney itself is not remain valid in the event of bankruptcy of the pledgor. That the irrevocable power of attorney in fact is a contract and therefore at the time the pledgor revoke, it cause such power of attorney be ceased and the pledge may only have a recourse for damages resulting for breach of contract. ${ }^{9}$ The Netherland Supreme court held on 1 April 1927 stated that the pledgor may give power of attorney to sell the pledged property only after the debtor is in default. If the pledgor gives power of attorney to sell pledged property before his is in default, then there will be unequal bargain of position. However according to H. J. Snijder under the current Netherlands Law, provision concerning the execution of share pledge agreement cannot be bypassed by irrevocable power of attorney.

${ }^{7}$ J. Satrio. (2007). Hukum Jaminan Hak-Hak Jaminan Kebendaan. Bandung: PT. Citra Aditya Bakti. p.

115.

${ }^{8}$ J. Satrio. (2006). Eksekusi Benda Jaminan Gadai in Jurnal Hukum dan Pembangunan. Jakarta: 2006.

p. 7.

${ }_{9}^{9}$ Soenardi Pardi. The Current Development of the Enforcement of A Pledge of Shares in Indonesia. p.

8. 
Kartini Mulyadi comments that as a practical matter debtors gave irrevocable power of attorney to cancel the pledge of shares agreements and after such pledges were ceased that the debtors give irrevocable power of attorney to sell such shares. ${ }^{10}$ However during the Seminar on Restatement of Share Pledge Execution, dated 7 April 2010 Eliana Tanzah SH and Fred Tumbuan, SH did not agree to this kind of legal practice. According to Fred Tumbuan it constitutes an effort to evade a law of pledge.

The District Court of South Jakarta issued the Court Decree No. 332/PDT.P/2001 PN.Jak.Sel to the Court Decree No. 343/Pdt.P/2001/PN.Jak.Sel validating private sale of pledged shares in private under irrevocable power of attorney. My critic to the District Court of South Jakarta is that those irrevocable power of attorney had been concluded before the debtor-pledgor was in default.

\section{The Fourth Legal Issue}

Based on article 1150 of the Civil Code, the Pledgee is the preference creditor who superior to concurrent creditor in satisfying its claim. In case the pledged shares being executed the pledgee take the result first in order to take recourse against the proceeds for the amount of the debt including interest and cost. Under the article 1155 paragraph 1 the Civil Code, unless otherwise stipulated by the parties once the debtor is in default the creditor-pledgee is entitle to proceed to sell the pledged property by way of public auction unilaterally without having to involve the pledgor and autonomously without need for the pledgee to approach the court as to obtain court order or ruling. By virtue of the provision in article 1155 paragraph 1 that parties may stipulate and agree that the pledge shall not enjoy "the parate executie right" to sell by public auction. In conclusion the right of the creditor-pledgee to enjoy parate executie is exist by operation of law without approval from its debtor.

However, the provision concerning judicial sale by way of auction is applicable only for movable tangible property and share to bearer as well. According to Setiawan SH in his paper "Aspek-aspek Huku Pemilikan Saham", the right of bearer shareholder is exist in his physical possession on the said share similarly to article 534 of the Civil Code that physical possession on tangible good creates assumption that he possess it for his interest. Furthermore, the rule of transfer of title for tangible movable good in article 612 of the Civil Code is similar to the rule of transfer of title for share on bearer through physical possession. ${ }^{11}$

On the other hand for personal lien there is special rule to make transfer of title. According to article 56 of the Law No. 40 Year 200 concerning Corporation, transfer of title of personal share shall be performed by the deed of transfer of title. This deed shall be notified in written to the corporation.

${ }^{10}$ Kartini Mulyadi. (2010). Beberapa Catatan Mengenai tulisan yang berjudul The Current Development of the Enforcement of a pledge of shares in Indonesia in Seminar Restatement Tentang Eksekusi Gadai Saham, Jakarta: 7 April 2010. p. 5.

11 Setiawan. (1990). Aspek-Aspek Hukum Pemilikan Saham: Penyalahgunaan Badan Hukum dan Penyitaan Saham in Varia Peradilan No. 52 January 1990. p. 116. 
Furthermore the Board of Management shall register it in shareholder register. Therefore the execution of personal share cannot be performed through auction.

\section{5. $\quad$ Fifth Legal Issues}

Article 60 the Corporation law mentions that the validity of share pledge agreement is made by notification to the corporation issuing the said pledged share. With regard to shares registered and traded at stock market, Article 1.1. juncto article 3.6.1 of regulation issued by Securities Custodian Centre says that a person registered as the owner of securities account may encumber his Securities by way of making application to the Securities Custodian Centre. Furthermore article 3.6.2 KSEI mentions that encumbered securities cannot be traded for settlement of security trading. My critique to this regulation is that the debtor-pledgor is still has authority to deregister such pledge of shares and therefore it undermine the interest of creditor-pledgee.

According to my opinion since the nature of pledge is accessory/independent to the main contract such as loan agreement. It is necessary for the creditor to confirm its debtor that as long as the debt has not been paid up then the pledge of share shall be considered still exist and valid even though the debtor deregisters it from security account. Alternatively, article 3.6.2 Regulation of Central Custodian Centre shall be amended that in case the debtor wants to deregister such pledge of shares he is required to obtain consent from his creditor.

Concerning the execution of pledged property by banks, Article 6 letter K of the Banking law No. 7 Year 199 mentions that in the event of default the bank may purchase such collateral by auction and it must cash it as soon as possible. However when the pledged shares are registered at capital market and stock exchange, the banks face fluctuation of price. Moreover due to monetary crisis the value of pledged share will be substantially decrease and therefore it is not necessary for banks to cash it as soon as possible. In my opinion in case the pledged shares are glistered in capital market banks may sell the pledged shares through two experts brokers under article 1155 paragraph 2 of the Civil Code without auction. Banks and debtors have similar interest to wait and to have the price of share increase before selling it. The price of shares depend on market price at stock market and therefore it does not constitute appropriation.

However in case Bank IFI versus Ir. Fadel Muhamad, the Supreme Court held that the conduct of Bank IFI took over without auction PT Bukaka shares that registered at stock exchange and did not cash it as soon as possible constitutes a tort violating article letter $\mathrm{k}$ of the Banking Law and article 1154 of the Civil Code the pledgee may seek and to obtain a court order or ruling stipulating an alternative method of sale and then proceed to sell the pledged property according the manner as stipulated by the Court in the court order and use the proceeds of sale to settle the outstanding debt, interest and cost 
incurred. According to Fred B. G. Tumbuan ${ }^{12}$ and J. Satrio ${ }^{13}$ article 1156 is mandatory in nature and cannot be waived by the parties. It is both a right conferred on the pledgee as well as requirement to be meet by the pledgee. That every pledgee has the right to request the judge determine and stipulate in a court order the manner or method in which he can proceed to sell the pledged property without public auction. Moreover according to Fred B. G. Tumbuan, in the situation where the pledgor and pledgee have not agree to an alternative method of sale other than by way of public auction, still as provided for in article 1156 the pledgee can proceed to ask the court to allow it to sell the pledged property such as by way of private sale. ${ }^{14}$

Furthermore, Fred B. G. Tumbuan mentioned that in Beckkett PTE LTD case where the pledgor and pledgee have expressly agreed between themselves to a particular method of sale by the pledge other than public auction, the following points are to be noted: First, such agreement between the pledgor and pledgee to an alternative method of sale is permitted under article 1155 and 1156 of the Civil Code. Secondly upon the default of the pledgor, the pledgee is still required under article 1156 paragraph one to proceed to obtain a court order permitting the said agreed alternative method of sale. Thirdly, where the agreement between the pledgor and the pledgee as to alternative method of sale is already in existence, that agreement forms the basis of the request of the pledge to the court for a court ruling or order stipulating that he may so proceed by the method of selling in question. ${ }^{15}$

Article 115 of the Civil Code, provides second alternative which is when the pledgee desire to retain the pledged property for himself toward settlement of the debt with interest and cost. In such situation the pledge is required to obtain a court order and the court must stipulate the value of the pledged property. The value of the pledged property as determined by the judge shall be set off against the liability of the debtor/pledgor. When the value of the pledged property is higher than the obligation of the debtor/pledgor. ${ }^{16}$

According to Fred B. G. Tumbuan it must be noted that the requirement that the court order stipulates the value of the pledged property is only requires when it permits the pledgee to retain the pledged property, because it deviates from a cardinal principle in the Civil Code that the debtor/pledgor and the creditor/pledgee cannot be legally agree that the creditor/pledge become the owner of the pledged property. ${ }^{17}$ Therefore in conclusion when a pledgee file petition to ask the judge determining a method of sale there is NO requirement to stipulate the value or price of pledged property. Furthermore, J. Satrio confirms that article 1156 paragraph one is available for the sale of pledged property without market price such as the sale of personal or

${ }^{12}$ Fred B. G. Tumbuan on his Legal Opinion (Case between Beckkett PTE LTD and Deutsche Bank AG and PT Dianlia Setyamukti in The High Court of The Republic of Singapore) Point 47

${ }^{13}$ J. Satrio. Op. Cit. p. 9.

${ }^{14}$ Fred B. G. Tumbuan. Op. Cit. Point 48.

15 Fred B. G. Tumbuan. Ibid. Point 50.

${ }^{16}$ Fred B. G. Tumbuan. Ibid. Point 52.

${ }^{17}$ Fred B. G. Tumbuan. Ibid. Point 55. 
registered share. In such sale of pledged property involving public corporation shares, it shall be performed at a capital market involving a middle-man as regulated in article 1155 paragraph 2 of the Civil Code. ${ }^{18}$

For comparison, H. J. Snijder in his paper "Pledge in General and Pledge of Shares including the Enforcement Under Netherlands Law", states that under article 7:53 jo. Article 7:54 para Nieuw BW, the secured creditor, when the condition for execution are met, may appropriate the pledged property if so agreed and net the value of the securities with the sum due by it. The valuation of such securities is based on their market value or value on an exchange. This provision is the exception of the rule laid down in article 3:235 Nieuw BW that the pledge is not entitled to appropriate the pledged property. ${ }^{19}$

According to article 1156 paragraph 1 of the Civil Code, the pledgee shall seek and obtain the court order to execute the pledged property. It has raised an issue whether under the Indonesian Civil Code the Pledgee shall seek and obtain the court order under the article 1156 by "Penetapan" (court decree) or whether it was required to produce by way of "Putusan" or a court verdict. "Penetapan" is the court order issued by Indonesian Court in response to filed petition, which is an ex parte. It is unilateral and one-sided involving the petitioner only. In contrast "Putusan" refers to a complete court procedure or "inter-partes" full contested Court proceedings.

At present there is no express stipulation under the Civil Code whether article 1156 requires the pledge to obtain the court order by "Penetapan" or "Putusan". However, two publications both by former Chief Justice of the Indonesian Supreme Court deal with the issue whether such private sale requires "Penetapan" or "Putusan".

The late Chief Justice Wirjono Pridjodikoro clearly stated that the pledge obtains an ex parte or "Penetapan" court ruling. "In accordance with article 1156 of the Civil Code, the pledge can embark on different avenue (that is as opposed to conduct a sale in public accordance with local customs an upon the usual conditions as set out in article 1155), namely requesting the judge that the judge "menetapkan" (that is "determine" which is a transitive verb in active form) for the noun "Penetapan") the manner as to how the sale shall be carried out, or, to ditetapkan (that is, determine, again, a transitive verb (in passive form) for the noun "Penetapan") that the pledged article become the property of the pledge in payment of the debt of the borrower in whole in part). ${ }^{20}$

Another former Justice of the Indonesian Supreme Court, Subekti, also states that article 1156 requires the pledge to obtain an ex parte or "Penetapan" court ruling:

"...He is entitle to recover the debt from the sale proceeds of the pledged property, if the debtor is in default. He can himself conduct the sale of the

18 J. Satrio. Loc. Cit. p. $7-8$.

${ }^{19}$ H. J. Snijders. Op. Cit. p. 2.

${ }^{20}$ Wirjono Prodjodikoro, Hukum Perdata tentang Hak atas Benda. (Jakarta: Intermasa, 1986), p. 
property, but he also can request intervention of the judge ("perantaran hakim"). By the judge, it can be determined ("ditetapkan") that the pledged good become the property of the pledge as repayment of all part of indebtedness".

Professor Subekti points out in his book that the peldgee may upon the default of the pledgor sell the pledged good in public auction under article 1155 or he can ask for court intervention, it can be "ditetapkan" by the judge that the pledged property can become the property of the pledgee..$^{21}$

Fred B. G. Tumbuan noted that the words "menetapkan" and "ditetapkan" were deliberately and intentionally used by the two former Chief of the Supreme Court and it was their opinion that article 1156 in fact is to refer to "Penetapan" and not "Putusan" and he shares the same view with them. Therefore Fred B. G. Tumbuan concluded that the right Court process and Court ruling required of the pledgee under article 1156 is "Penetapan". ${ }^{22}$

Moreover, the well-known scholar Mr. J. Satrio stated "In addition to his right to sell, the pledgee in the event of default of the debtor or the pledgor, can still take another avenue, i.e. (a) petition that a judge determine the manner of the sale of the pledged property..." ${ }^{23}$ Furthermore J. Satrio explains that the right of pledge to sell such pledged property under article 1156 paragraph 1 of the Civil Code is already exist sice it given by the law and therefore it is not necessary for a creditor-pledgee to involve a debtor. As a legal consequences, the pledgee has the right to file petition asking a judge to determine the manner of the sale of the pledged property without suing a debtor at court. ${ }^{24}$

Furthermore Kartini Mulyadi and Gunawan Widjaya also stated that:

"... a little different from the provision in article 1155 of the Civil Code which allos the creditor to sell on its account the pledged property and to recover the repayment of the whole principal amount, interest and cost due to him, the provision of article 1156 provides for a sale mechanism based on Penetapan Pengadilan (i.e. ex parte Court Ruling). In this latter event, after the sale has been conducted by the creditor based on the court order, then the creator will be obliged to immediately notify the pledgor, which accordance with the article 1156 of the Civil Code, is to be conducted on the immediately succeeding day if there is daily postal service or telegraphic communication or if none., by the first departing post. ${ }^{25}$

${ }^{21}$ R. Subekti, Pokok-Pokok Hukum Perdata, (Jakarta: Intermasa, 2003), p. 81

${ }^{22}$ Fred B. G. Tumbuan, Loc. Cit. point $81-83$.

23 J. Satrio, Loc. Cit. p. 126.

${ }^{24}$ J. Satrio, "Eksekusi Benda Jaminan Gadai", Loc. Cit. p. 10.

${ }^{25}$ Kartini Mulyadi \& Gunawan Widjaya. (2007). Hak Istimewa, Gadai \& Hipotik. Jakarta: Kencana Prenada Media Group. p. 175 
In contrast, the former Justice of Supreme Court Marianna Sutadi, mentioned that according to article 1155, the pledged share shall be sold by way of public auction and based on article 1156, a creditor shall bring the case as a plaintiff and sue a debtor as a defendant to obtain a court verdict ("Putusan") before executing such pledged shares. ${ }^{26}$

Regarding Marianna Sutadi's opinion it must be noted that according to M. Yahya Harahap in his book Ruang Lingkup Permasalahan Eksekusi Bidang Perdata, page 233 that an execution of encumbered property shall be performed under leadership and supervision of the Chief of District Court. Therefore in doing his duty as a chief of a District Court, he has discretionary power to consider whether such execution shall be performed by method of court decree ("Penetapan") or Court Verdict ("Putusan"). ${ }^{27}$

In addition to those, Mellisa Yuan in her thesis stated that if the debtorpledgor is not cooperative and does not voluntarily perform its obligation then under the article 1156, the creditor-pledgee shall bring the said case to a court as a plaintiff and shall sue the debtor-pledgor. ${ }^{28}$ Furthermore, she argued that it is not necessary for the creditor-pledgee to file petition to obtain a court decree ("Penetapan") in order to execute the said pledged shares. If the court issue the Court Decree ("Penetapan"), then it contravenes with the Supreme Court's Guide for Performing a Court Duty and Administration, that stated: The District Court shall not issue decree to legalize one and some people have an ownership or a title of property in question; The District Court shall not issue a decree to legalize that such document or deed is valid. ${ }^{29}$

Soenardi Pardi noted that there was a similar discussion in Netherland regarding the case brough before the High Court in Amsterdam in 1933 showed that there was noe authentic interpretation of the term vorderen. However the court held the word vorderen was refer to a contentious proceedings and the Dutch Supreme Court was never considered this issue. However Mr. Paul Scholten made an annotation for the Hoge Raad decision 1934, suggested that the procedure contemplated was a procedure similar to ex parte proceedings. This issue has been clarified in the Nieuw Burgerlijk Wetboek that the term used now is verzoek (permohonan). ${ }^{30}$

The author, follows Fred B. G. Tumbuan, Wirjono Prodjodikoro, R. Subekti, J. Satrio and Kartini Mulyadi opinions' for some reasons: The position of pledgee as secured creditor is different from the position of unsecured creditor. For unsecured creditor, before executing the debtor's property he must file his case as a plaintiff and sue a debtor in court. The unsecured creditor who succeeded in obtaining a final court verdict against his debtor may ask the

\footnotetext{
26 Mariana Sutadi. (2007). Beberapa Penyelesaian Permasalahan oleh Pengadilan Menurut UndangUndang No. 40 tahun 2007. Jakarta: 28 November 2007. p. 13.

${ }^{27}$ M. Yahya Harahap. (1993). Ruang Lingkup Eksekusi Bidang Perdata. Jakarta: Gramedia Pustaka Utama. p. 233.

${ }^{28}$ Melisa Yuan. (2005). Penjualan Gadai Saham Berdasarkan Penetapan Pengadilan Negeri: Analisa Kasus Gadai Saham PT ABU di DBA. Depok: FHUI Tesis Program Magister Kenotariatan FHUI. p. 70 - 71.

${ }^{29}$ Melisa Yuan. Ibid. p. 77.

${ }^{30}$ Soenardi Pardi. Op. Cit. p.7.
} 
President of District Court to issue a writ of execution. On the contrary, laws make ease secured creditors in executing their rights as follows:

For example, the mortgagee under article 224 of the Civil Code Procedure may execute such mortgage without having the court verdict punishing the debtor to pay the said debt. It is not necessary for the mortgagee to bring the case as the Plaintiff and to sue the debtor as the defendant. He just request the court to issue the writ of execution and do judicial sale by auction. Moreover under article 1178 of the Civil Code, the mortgagee may make agreement with the mortgagor to do public sale or auction without having court order. The similar procedure provides in article 20 of the Security Transaction over Land Its Affixed Building Act, that the mortgagee just simply file petition to the court for having a writ of execution or alternatively under the agreement between the mortgagor and the mortgagee it is possible to do public sale or auction without court order. Moreover, the execution or mortgaged property may be performed by private sale as long it based on the agreement between the mortgagor and mortgagee for obtaining the best price of them. Furthermore, article 29 of the Fiduciary Transfer of Ownership Act, also makes ease the civil procedure for execution. The creditor holding fiduciary right may execute such encumbered property by just simply file petition asking the court to issue the writ of execution and do public sale by auction. He also may make agreement with his debtor to execute and encumbered property by auction without having the court order. It is also possible to perform private sale over such encumbered property to have the best price for them.

For comparative study, the Nieuw Netherlands Burgerlijk Wetboek provides the rule in executing pledge as follows:

Article 249

1. Where the debtor is in default of paying that for which the pledge serves as security, the pledgee is entitled to sell the pledged property and to take recourse against the proceeds for what is owed to him.

2. The parties may stipulate that no sale will take place until the judge, upon demand of the pledgee, has determined that the debtor is in default.

3. A Pledgee or seizor with a lower ranks can only sell the pledged property subject to the higher ranking the rights of pledge.

Article 250 (3.9.2.11)

1. The sale take place in public according to local custom and upon usual conditions.

2. The sale of pledged property which can be traded in a market or at an exchange may take in market through the intervention of an appropriate broker or at an exchange through the intervention of a qualified intermediary, according to rules an usages in force for an ordinary sale at such market or exchange.

3. The pledgee has the right to bid. 
Article 251 (3.9.2.12)

1. Unless otherwise stipulated, the President of the District Court may determine, at the request of the pledgee or the grantor of the pledge, that the pledged property will be sold in a manner which deviates from the proceeding article; at the request of the pledgee, the President of the District Court may also determine that the pledged property will remain with the pledgee as buyer for an amount to be determined by him.

2. The pledgee who has become entitled to proceed to a sale may agree with the grantor to a manner of sale which deviates from the proceeding article. Where the pledged property is encumbered with a dismembered right or is under seizure, the cooperation of the holder of the dismembered right or of the seizure is also required. ${ }^{31}$

Futhermore, H. J. Snijders explains that the judicial permission for private sale must be requested by pledgor or pledgee and it cannot be by passed by an irrevocable power of attorney. Although the pledge must also comply with the restrictions regulated in the article of the company for the disposal and transfer of shares, but the right to pledge a beared share in public limited company may not be restricted to excluded by the article of association. Moreover the sale of pledged shares in public is rare phenomenon in the Netherlands and its regularly occurs that the request for private sale is granted. ${ }^{32}$

\section{Conclusion}

a. The creditor-pledgee is entitle to extent the duration of pledge share agreement without the debtor consent if it is clearly that the intent to conclude share pledge agreement is to secure payment of the whole debt. Moreover the nature of share pledge agreement is accessory to the debt arise out of main contract.

b. Article 1154 paragraph 2 of the Civil Code states that in case the pledgor is not entitle to conclude the pledged share it cannot make the pledgee responsible for that. However, the aggrieved third party may ask the court to declare such pledged share is void in case the pledgee knows that the pledgor is not entitle to conclude it.

c. The irrevocable power of attorney to sell pledged shares before the debtor is in default does not constitute appropriation by itself. However there is an opinion that the execution of pledge share agreement shall be performed by court order in accordance to article 1156 of the Civil Code. It cannot be bypassed by irrevocable power of attorney.

31 PPC Haanapeel \& Ejan Mackaay. (1990). Nieuw Netherland Burgerljik Wetboek: Het Vermogenrecht. Deventer: Kluwer. p. 108 - 109.

${ }^{32}$ H. J. Snijder. Ibid. p. 5. \& 7. 
d. Under the article 1155 paragraph 1 of the Civil Code, the creditorpledgee is entitle to sell the pledged property by auction without court order. It is not necessary for the creditor to obtain the debtor consent, unless there is a contrary agreement. However the provision to sell the pledged property by auction is only applicable for movable tangible good and share to bearer.

e. In case the pledged shares are traded at stock market they shall be registered at security account. Since under the KSEI Regulation, the debtor-pledgor is still entitle to deregister such pledge of shares, it is necessary to the creditor-pledgee to confirm its debtor that the pledge of share is still valid as long as the debt has not been paid up. In doing execution, the pledgee shall rely on article 1155 paragraph 2 of the Civil Code that such judicial sale is performed by two expert brokers without auction. It does not constitute appropriation since the result of sale depends on market price at stock market.

f. In case the pledged shares are issued by close corporation, and the creditor-pledgee want to sell the pledged shares in private, he shall file petition to obtain court decree to sell the pledges shares in private for the purpose of execution.

\section{Bibliographies}

Gautama, Sudargo. (1995). Introduction to Indonesian Business Law. Bandung: PT. Citra Aditya Bakti.

Haanapeel, PPC \& Ejan Mackaay. (1990). Nieuw Netherlands Burgerlijk Wetboek: Het Vermogenrecht. Deventer: Kluwer.

Harahap, M. Yahya. (1993). Ruang Lingkup Eksekusi Bidang Perdata. Jakarta: Gramedia Pustaka Utama.

Hasbullah, Frieda Husni. (2005). Hukum Kebendaan Perdata. Jakarta: Ind-Hill Co.

Mulyadi, Kartini. (2010). Beberapa Catatan Mengenai tulisan yang berjudul The Current Development of the Enforcement of a pledge of shares in Indonesia in Seminar Restatement Tentang Eksekusi Gadai Saham, Jakarta: 7 April 2010.

Mulyadi, Kartini \& Gunawan Widjaya. (2007). Hak Istimewa, Gadai \& Hipotik. Jakarta: Kencana Prenada Media Group.

Pardi, Soenardi. The Current Development of the Enforcement of A Pledge of Shares in Indonesia.

Prodjodikoro, Wirjono. (1986). Hukum Perdata tentang Hak atas Benda. Jakarta: Intermasa.

Satrio, J. (2007). Hukum Jaminan Hak-Hak Jaminan Kebendaan. Bandung: PT. Citra Aditya Bakti.

Satrio, J. (2006). Eksekusi Benda Jaminan Gadai in Jurnal Hukum dan Pembangunan. Jakarta: 2006.

Setiawan. (1990). Aspek-Aspek Hukum Pemilikan Saham: Penyalahgunaan badan Hukum dan Penyitaan Saham in Varia Peradilan No. 52 January 1990, p. 116.

Subekti. (2003). Pokok-Pokok Hukum Perdata. Jakarta: Intermasa. 
Snijder, H. J. (2010). Pledge in General and Pledge of Shares in Particular Including the Enforcement under Netherlands Law in Seminar Eksekusi Saham. Jakarta: 31 March 2010.

Sofwan, Sri Soedwi Masjchun. (1977). Beberapa Masalah Pelaksanaan Lembaga Jaminan Khusus Fiducia di Dalam Praktek dan Perkembangannya di Inodnesia. Jogjakarta: FH UGM.

Sutadi, Mariana. (2007). Beberapa Penyelesaian Permasalahan oleh Pengadilan Menurut Undang-Undangg No. 40 Tahun 2007, Jakarta: 28 November 2007.

Tumbuan, Fred B. G. Legal Opinion (Case between Beckkett PTE LTD and Deutsche Bank AG and PT Dianlia Setyamukti in The High Court of The Republic of Singapore).

Tumbuan, Fred B. G. (2007). Presentation on New Company Law in Seminar Sehari Aspek-Aspek Penting tentang Undang-undagn No. 40 tahun 2007. Jakarta: November 2007.

Yuan, Melisa. (2005). Penjualan Gadai Saham Berdasarkan Penetapan Pengadilan Negeri: Analisa Kasus Gadai Saham PT ABU di DBA. Depok: FHUI Tesis Program Magister Kenotariatan FHUI. 